\title{
Black Women Leading Education for Social Justice in the Region of Baixada Fluminense, Rio de Janeiro, Brazil
}

\author{
Rosangela Malachias ${ }^{1 *}$, Laudilea Aparecida de Lourdes Laudino ${ }^{2 *}$ and \\ Teresa Cristina dos Santos Balbino ${ }^{2 *}$ \\ ${ }^{1}$ Universidade do Estado do Rio de Janeiro - Faculdade de Educação da Baixada Fluminense (UERJ-FEBF) and Programa \\ de Pós-Graduação em Educação e Demandas Populares da Universidade Federal Rural do Rio de Janeiro (UFRRJ), Rio de \\ Janeiro, Brazil, ${ }^{2}$ Universidade do Estado do Rio de Janeiro - Faculdade de Educação da Baixada Fluminense (UERJ-FEBF), \\ Rio de Janeiro, Brazil
}

\section{OPEN ACCESS}

Edited by:

Kay Fuller,

University of Nottingham,

United Kingdom

Reviewed by:

Michael W. Apple,

University of Wisconsin-Madison,

United States

Ira Bogotch,

Florida Atlantic University,

United States

*Correspondence: Rosangela Malachias rosmalach@gmail.com Laudilea Aparecida de

Lourdes Laudino

Ilaudilea@gmail.com

Teresa Cristina dos Santos Balbino

tetecris17@gmail.com

Specialty section:

This article was submitted to

Leadership in Education,

a section of the journal

Frontiers in Education

Received: 12 December 2019

Accepted: 20 May 2020

Published: 23 July 2020

Citation:

Malachias R, Laudino LAL and Balbino TCS (2020) Black Women Leading Education for Social Justice in the Region of Baixada Fluminense, Rio de Janeiro, Brazil. Front. Educ. 5:85

doi: 10.3389/feduc.2020.00085
This paper explores the interface between the fields of Education and Communication with respect to developing narratives that can identify leadership among women who live daily with social inequalities and violence. These studies, debates, and research took place at the AFRODIÁSPORAS Research Center on Black Women, Audiovisual Culture, and Educommunication in Urban Peripheries at the Rio de Janeiro State University (UERJ) School of Education from Baixada Fluminense (FEBF), Duque de Caxias city, RJ, Brazil. Two studies were chosen as examples of the specific leadership developed by black women using concepts from Education, Communication, Intersectionality, and a daily struggle against prejudice and racism. The first study reports the experiences of a black deaf woman who teaches sign language alongside the history and culture of black deaf people. The second introduces a young black filmmaker who produces new portrayals of the Baixada Fluminense (BF) region.

Findings: Both studies show the authorship of the interviewees, demonstrating that education and black consciousness empower people to become leaders who respond to social exclusion. Non-formal education has been employed as a method to propagate narratives refuting stereotypes and colonial beliefs that still appear on the curriculum of formal education and in hegemonic media. These two young black women are protagonists, educommunicators, social activists, and leaders.

Keywords: black women, leaders, communication-education interface, black women, leaders, communicationeducation interface, deafness, filmmaker

\section{INTRODUCTION-WHO WE ARE}

As a member of the social justice-focused international network Women Leading Education Across Continents (WLE), which launched in 2007, Rosangela Malachias, the first author, made contact with the leadership concept as a main issue in the education field. In 2015, she became a professor in the Department of Sciences and Education Fundamentals and coordinator of the AFRODIÁSPORAS Research Center at the School of Education from Baixada Fluminense (FEBF) at Rio de Janeiro State University (UERJ), hereafter referred to as UERJ-FEBF. This provided her with the opportunity to start local 
investigations from the perspective of leadership conceptualization across the continents.

It is essential to explain that, in Brazil, the concept of "leadership" ("Liderança," in Portuguese) is not regularly employed in Education courses but often appears in Business, Administration, and Economics, such as in research about "Women and leadership: obstacles and gender expectations in managerial positions" (Hryniewicz and Vianna, 2018, p. 332334), and in Public Health, emphasizing "education, leadership, and development of partnerships in the field of nursing" (Mendes et al., 2016, p. 4) and identifying the "relevance of leadership and its context of development, in which Nursing students can be leaders" (Neves and Sanna, 2016, p. 734; 736-739). Religion courses also consider leadership as an important concept. Silva and Holanda (2008, p. 378-379) presented the experiences of "pleasure and suffering" of religious leaders; Silva (2009, p. 276) studied the relationship between "religion, sexuality, and power" in religious and political leadership in the Pentecostal Church. However, we did find scientific articles written in Portuguese about "leadership in Education" related to schools, teachers, and administrators from Portugal (Costa and Bento, 2015; Neves and Coimbra, 2019). Further conceptualization of educational leadership in the Brazilian context is needed.

Social justice, human rights, and intersectionality became the theoretical framework and basis of this new line of research on Women Educators in Baixada Fluminense (BF). Most are leaders, albeit they are not conscious of their protagonist role. Because of this, our studies identify the process of educomuncação (educommunication) and advocacy praxis (Malachias, 2017), facilitating themes such as inclusion, legislation, deafness, cinema, and social media.

Duque de Caxias, where UERJ-FEBF is located, is one of twelve dormitory cities that belong to Rio de Janeiro metropolitan region called Baixada Fluminense (BF). These cities are Belford Roxo, Duque de Caxias, Guapimirim, Itaguaí, Japeri, Magé, Mesquita, Nilópolis, Nova Iguaçu, Paracambi, Queimados, São João de Meriti, and Seropédica. BF is known by high levels of violence. Since 2016, Duque de Caxias has led on incidents of domestic violence and femicide in the region.

The concept of social justice generates tensions because it is multiple (Gewirtz and Cribb, 2011). According to Rawls (2002), social justice can be understood as "the way in which the main institutions [...] distribute fundamental rights and duties and determine the distribution of advantages of social cooperation" (Rawls, 2002, p. 6). The absence of public policies and political commitment can partially explain the reality of exclusion in the $\mathrm{BF}$ region.

During four and a half centuries of slavery, black bodies were legally treated as moving objects and targets of violence (torture, beatings, and death). In the nineteenth century, Duque de Caxias had a seaport where millions of slaves were brought to Brazil. This continued after the ban on the slave trade (1850), and, still today, the region has the largest population of African descent in Rio de Janeiro state.

In the twenty-first century, the bodies of black men, women, and children remain dehumanized. Daily racist manifestations take place on the streets, in football stadiums, in classrooms, on the internet-with prolific name-calling such as "monkey, black, rubbish!" (Malachias, 2019, p. 153).

Brazilian studies on black people in education have contributed to the gradual recognition, still ongoing, of the legitimacy of the claims made by the black population against social and economic inequalities, barriers to accessing education, and low student retention regardless of whether there is affirmative action or not. A huge emphasis has been on reforming the curriculum in basic education by including the history and culture of excluded populations, such as the indigenous peoples and African descendants.

According to Malachias (2019, p. 149), the studies by black scholars about black people's portrayal in the media center on the absence of good representation and the abundant use of stereotypes. Gonzalez (1988) denounced theoretically the delimitation of black women's bodies as spaces aimed at servitude and sexuality. Therefore, steeped in this symbolism, soap operas, advertising, and publicity still exclude black people, who would not fit as a positive referential model. Class exploitation and racial oppression are articulated and work as an effective mechanism that denies blacks access to material and symbolic goods (Hasenbalg, 1979). Of course, this has been changing slowly, and this can be understood to have occurred due to an enhancement of economic power on the part of black customers. But despite the changing nature of racism, it totally or partially denies black humanity (Gonzalez and Hasenbalg, 1982).

With respect to education, Pinto (1993), one of the pioneers in researching black people's schooling in the twentieth century, highlighted actions of the Black Movement in the 1930s-Frente Negra Brasileira (FNB)/Brazilian Black Front and other institutions such as the Movimento Negro Unificado $(M N U) /$ United Black Movement. For her:

(...) if before the black simply wanted to educate himself (sic), gradually he also starts to demand from the formal educational system and Brazilian society, the recognition of his culture, his way of being, and his history. It is an effort that aimed not only at changing the minds of white people but mainly at strengthening the ethnic identity of black people (Pinto, 1993, p. 28).

Considering centuries of slavery and the action of European colonialism as a civilizing paradigm supported by multiple forms of knowledge erasure of those of indigenous and African origin, resistance still happens. Women's struggle for access to social justice is an intercontinental demand, but it is also a Brazilian need for the poor and black populations. Both resistance and leadership movements face silencing about human rights and the normalization of stereotypes.

If we already know that the print, fictional, and audio texts about $\mathrm{BF}$ are intersected by stereotypes reinforcing inequalities, how can (black) women develop strategies in the fields of education and communication to confront prejudice, sexism, and racism?

Working at UERJ-FEBF we could observe that local and social movements have been working in order to develop practices and speeches against the violence and stereotypes persistently directed to this region. These actions occur mainly in the spheres 
of culture, such as music and cinema, education, and communitybuilding for the defense of rights (Malachias et al., 2018).

\section{RESEARCH CONTEXT}

The AFRODIÁSPORAS Research Center was launched in 2016 as a space created to bring together researchers, students, members of social movements or collectives, and other interested people from the Rio de Janeiro community who are committed to dismantling racism. The research addresses black feminism; black women; cultural production, audiovisual culture with black agents as protagonists; black and African photography and cinema; schooling processes and access to higher education for the black population; studies on the trajectories of black subjects; the thought of black intellectuals made invisible by the academy. All of these topics can be deepened by the interfacing of Communication and Education in ethnic-racial and gender relations, intersectionality, media studies, educommunication methodology, and advocacy practices.

The condition of being black women researchers makes us assume a leadership identity expressed in the first personI/We (Malachias, 2018). This option sets our thoughts on self-definition and self-assessment (Collins, 2016). Other black scholars did the same in studies about teachers (LawrenceLightfoot, 1997) or women of color artists because "their lives and contributions provide a readily accessible induction process into professional pathways where women of color are perpetually 'othered"' (Santamaría and Jaramillo, 2014, p. 318).

Students from UERJ-FEBF and educators who work in public schools at Baixada Fluminense, RJ, Brazil, are the target audience of AFRODIÁSPORAS. They are also leaders in the learning process about "the role of teachers" (Guilherme and Morgan, 2018, p. 783). Together, we are looking for stories, images, metaphors, methods, and theories that can build a local conception of leadership in education, focusing on women who live and/or work in BF.

The organization's work on the 6th WLE ConferenceFrom the Margins to Centers, in Duque de Caxias, RJ, Brazil (2017) contributed to the development of a new line of research in the AFRODIÁSPORAS Research Center aimed toward an understanding of a local concept of educational leadership related to women (some of them young) who are educators and leaders acting in formal spaces of education, e.g., schools and universities, but also working in NonGovernmental Organizations (NGO) and cultural forums, that is, non-formal education.

At AFRODIÁSPORAS, non-formal education is framed by Gohn's (2014) work, which considers it to be an educational process of a sociopolitical, cultural, and pedagogical character that develops learning and affects citizenship formation and the emancipation of subjects.

\section{INTERSECTIONALITY AND EDUCOMMUNICATION}

Talking about gender theory, Lumby (2015, p. 158) emphasized that "the advent of intersectionality theory challenged the methodological limitations of the field."
For her, "intersectionality demands more sophisticated methods for researching the complexity of individual lives" (Lumby, 2015, p. 158).

In the 1980s, Lélia Gonzalez, the black anthropologist and activist founder of MNU denounced the incapacity of the Feminist Movement-mostly composed by white women (housewives) - to understand the needs of black women (maids) (Gonzalez, 2008). Gonzalez introduced race/ethnicity and gender as intertwined categories in the class struggle for social and economic mobility (Gonzalez and Hasenbalg, 1982). Audre Lorde had already questioned white feminists whether they know "how do you deal with the fact that the women who clean your houses and tend your children while you attend conferences on feminist theory are, for the most part, poor women and women of Color? What is the theory behind racist feminism?" (Lorde, 1984).

This was the beginning of intersectional theorization. Some years later, Kemberlé Crenshaw gives us a name for the concept.

Intersectionality is a conceptualization of the problem that seeks to capture the structural and dynamic consequences of interaction between two or more axes of subordination. It deals specifically with the way in which racism, patriarchalism, class oppression, and other discriminatory systems create inequalities that structure the relative positions of women, races, ethnicities, classes, and others (Crenshaw, 2002, p. 177).

Another Brazilian black activist and medical doctor, Jurema Werneck, stresses that intersectionality shows differences including those among people who are victimized by racism. The concept enables the elaboration of tools, methods, and understanding (Werneck, 2016, p. 543). That is what happened in 2016 during the Black Awareness Week program organized by members of the AFRODIÁSPORAS Research Center. Three researchers (one man and two women) were invited to talk about their living conditions-they are deaf black people who speak by using LIBRAS (Brazilian Language of Signals). They silenced the audience, including me, Malachias, a black woman, activist, and researcher. How and why had I never thought about those differences?

Collins (2016) classifies the sociological steps taken by black women when they write about themselves. As an advisor, selfevaluation was my first step before accepting, 2 months later, the supervision of a student, Laudino, who had attended the three lectures and defined her theme: Black Deaf People and Double Difference.

Two Pillars of Education (Delors, 2000)-learning to know and learning to learn-were elected to guide our steps in the direction of blackness and deafness as categories of difference. Our key references were Furtado (2012) from Brazil and Hairston and Smith (1983) from the United States. Both authors have black deaf people as subjects from their work. In addition, this new approach would be crossed with intersectional considerations-race, ethnicity, deafness, audition, class, gender, age, schooling, etc.

One year later, we registered at the National Conference of Social Inclusion of the Deaf Black in Florianópolis city, Santa Catarina state, our presentation entitled "Learning to Know: Deaf Black People" (Laudino, 2019), and it was accepted in the "listeners" category. It is important to 
explain that the content, at that moment, was until Project of Research.

The first day of the conference was dedicated to the initial procedures of methodology. As listeners, we needed help to complete interviews. We explained the proposal to a deaf interpreter who was attending the conference and working in the organization helping listeners. She was a white student, literate in LIBRAS and Portuguese and an expert in reading lips. The color identification of this interpreter was mentioned, obeying the necessary intersectionality due to the theme of this work. Racism and racial prejudice, although present in Brazilian society, are not always understood by people, including in academic spaces. Logically, before starting the five interviews with black deaf people and filming them, the topic "learning to learn" was explained, and consent was given by them after a detailed explanation of the research objectives. Three broad questions were asked: (1) "How do you see the process of raising awareness among Deaf Black people? (2) "How do you observe the inclusion process in society?" (3) "How do you participate in society?"

For this article, we chose to present only one interview of the four conducted during the conference. The fifth interview was with a young high school student and was conducted at a public library in Rio de Janeiro. Ethical procedures had been followed, including providing an explanation of the research and securing informed consent, in the case of the school student from her mother. Soon, we aim to publish a specific text about the five black deaf people interviewed. The research was finalized and formally presented in May 2019.

Here, we hope to demonstrate how this black deaf woman can be classified as a leader in education, as can the young filmmaker protagonist of the second research described later. As educommunication praxis demands, different ecosystems were considered in a democratic process.

During the seventies and eighties, when a dictatorship context pertained in Latin American countries such as Brazil, Argentina, Chile, and Uruguay, two authors, the Brazilian Paulo Freire and the Uruguayan Mario Kaplun, were considered pioneers in the praxis of education as communication. The first introduced liberating education as a real possibility (Freire, 1987), and the second one considered that educating yourself is getting involved in a process of multiple communicative flows (Kaplun, 1999). It was a way of linking the fields of education with communication or shedding light on their interface, showing relevance to the critical development of media literacy, and defending the right of individuals to produce information and communication.

For Silva and Viana (2019, p. 8) "educommunication is concept and praxis" and it also occurs in artistic production. Indeed, not only schools but social spaces as a whole (institutions, companies) present communicative ecosystems (Soares, 2000) that promote the development of an awareness of the necessary management of communication processes. However, educational spaces need to develop democratic communication management.

Empowerment is a better word to define this young tenured professor, P. L. A. Ferreira, who is a black woman and an educator linked to the Federal University of Western Bahia located in the north of Brazil. Ferreira is the vice coordinator of the National
Federation of Education and Integration of the Deaf (Feneis). Her academic resume $\left(^{*}\right)$ presents her life experience, and, in it, social activism walks together with formal education but also with cultural practices, in which the communication and education interface appears. Ferreira was chosen as a lecturer of the National Conference of Black Deaf People (2017) and, years ago, in 2012, worked as an actress in a short film called "Jovem Força Surda 3" [Young Deaf Force 3] exhibited at the III Meeting of Young Deaf People in the Northeast (3rd EJSNE) in Ceará state.

* "several experiences in national movements: leader of the Deaf Movement in favor of Deaf Education and Culture in Bahia; Leader of the Black Deaf Movement in Brazil, and Leader of the Young Deaf Movement in João Pessoa and Salvador."

Ferreira shared perceptions and subjectivities of her own constitution as a black deaf woman:

"First comes the discussion about being black and then about being deaf, due to the fact that visually speaking, it is the aspect that first draws attention and secondly the issue of being a deaf person. (...) I am proud of my black identity and culture. Before, I had no identity, but I assumed it, and I am proud to be a deaf black woman and not feel myself inferior. It is important to say [teach] about my ancestors, as it says a lot about my own history (...)" (Ferreira, 2017, interview; Ferreira, 2018, p. 16).

The first perception being about color (race/ethnicity) was also stressed by all the coordinators of the Conference. In the Portuguese language black deaf ("negro surdo") or deaf black ("surdo negro") have the same meaning but, in the intersectionality approach, the first noun illustrates its relevance. For this reason, the Portuguese word "Negros" (Blacks) is in the first position in the conference name. As stated before, our role as researchers and "listeners" obliged us to ask for help from a translator. In that space, we were like non-Portuguese speakers who were communicating in Portuguese, the second language for that audience who were fluent in LIBRAS.

According to Skliar and Quadros, "the deaf social group treats as different from them, those (listeners) who are unaware of their visual experiences" (Skliar and Quadros, 2000, p. 15).

Deafness cannot be reduced to a pathology, which considers the deaf person as disabled and therefore focuses, all attitudes, educational and social, on hearing. To achieve this, medical interventions are carried out, speech therapy to increase listening capacity, to correct any "anomaly" (Calixto, 2018, p. 104). The other conception does not consider deafness as a disability but rather as a cultural difference mediated by symbolic communication, the sign language.

Blackness linked to deafness is a new theoretical issue in Brazil. Furtado (2012) brought this theme to the fore by focusing on the "double difference." For her, there is a prejudice against the cultural diversity of the deaf person in Brazilian society that refuses LIBRAS as a first language to the deaf and avoids talking about racism. These two behaviors show prejudice against sign language and maintenance of the belief in Portuguese language orality as the best conduct for deaf literacy. In the case of racism, the Brazilian myth of racial democracy is still propagated, in contradiction to the historical struggle of black movements in the twentieth and twenty-first centuries. 
Talking about LIBRAS literacy, Ferreira stressed that black consciousness is very important and can be enhanced when people learn the LIBRAS language. However, she criticized non-compliance with federal laws [10.436/2002-decree number $5626 / 2005]$, which makes the teaching of LIBRAS compulsory and the laws [10639/2003-11645/2008] that also make the teaching of the history and culture of Afro-Brazilian, African, and Indigenous people compulsory. The legislation also mandates the presence of an interpreter in schools and universities, but there is not complete compliance because most school administrators do not know about the federal legislation and how they can ask for support in implementing public policies. This demand has long been debated by black deaf people in annual conferences, as Ferreira states:

"Deaf people do not access the same curricular content as listening students because there is a lack of adaptation and improvement of teaching materials and resources. This lack of methodology and materials adapted for the deaf in the academic and school environment occurs regarding the contents already enshrined in the official curriculum and those about ethnicracial relations because we are a linguistic minority" (Ferreira, 2017, interview).

Focusing on this situation through an intersectionality lens, this "lack of access to content about ethnic-racial relations has implications for the way these subjects construct representations about being deaf black" (Ferreira, 2017, interview).

The response about what her social role is reveals criticism and hope. Ferreira said that "LIBRAS literacy is a right still accessible for few people, and prejudice against the black population is huge, but an awareness about equity is growing in the society and this can help the struggle for rights" (Ferreira, 2017, interview).

\section{CULTURAL AND SOCIAL ACTIVISM DEVELOPING LEADERSHIP}

Poverty, disparities, and violence are some words employed in mainstream media about the BF region; however, the interfaces between female activism, popular cinema, and education have valued the local history and culture, creating new realities and subjectivities. With little or no financial support, the films made at $\mathrm{BF}$ enable a process of leadership, activism, and the authorship of filmmakers.

One of these creators is Lu Brasil (LB). Her work was chosen as a focus at the AFRODIÁSPORAS Research Center. The theoretical knowledge about education, together with her choices of places and cinematic frames, became a vehicle for counterhegemonic narratives, a way to display images and develop metaphors about the $\mathrm{BF}$ region. We identified her movies and graffiti art as practices of educommunication inside a non-formal education process.

So, how might we interview a filmmaker? By filming her. This method was also suggested by LB herself. She wanted to be interviewed together with a group of young women filmmakers having the FEBF's building as the scenario. After a few attempts to schedule this appointment, without success, this meeting was canceled because of calendar incompatibility. Because of this, LB went alone to FEBF. Before filming her, she gave consent for her testimony to be published and answered a previous questionnaire sent to her by email. LB defined herself as being "a young black woman, graffiti artist, filmmaker, actress, and pedagogical specialist with a master's degree in Education."

Her interest in movies started when LB became a student on a short course about film production. It was offered by "Mate com Angú" movie club in Duque de Caxias City. This name celebrates the "Proletarian School of Meriti" built in February 13, 1921, and later named "Doutor Álvaro Alberto," father of a teacher called Armanda Álvaro Alberto. In the 1920s, Armanda was a teacher and a pioneer because she had an idea: serving tea and milk with cornmeal to poor children who did not learn to read because of famine. The school has received a nickname since its creation in 1921. Mate (Tea) com (with) Angu (Milk plus Cornmeal). It became the first school in Brazil to offer school snacks.

In 2002, the movie club "Mate com Angu" was founded to offer audiovisual culture as another kind of food to nourish the population of BF. It also became possible for local residents to make films without stereotypes, in opposition to regular images and speeches made by hegemonic media.

LB remembers: "And then I got to know this world when I started taking classes there in the Mate Movie Club. I learned with Igor and $\mathrm{HB}$, my teachers. They presented me with a world of possibilities. Understood? That's what Mate is, Mate is the world of possibilities within the audiovisual" ( $\mathrm{Lu}$ Brasil, 2018, interview).

Coombs and Ahmed (1974) was the first to classify the types of education developed outside the school in his book entitled "The world educational crisis" (1968), defining, without distinction, as non-formal and informal all non-school educational processes. Coombs gave them an intentional character during learning. For Coombs, non-formal education comprises systematic, educational, and organized activities carried out as part of the framework of the official system to facilitate specific types of learning for specific subgroups of the population, both adults and children. According to Gohn (2014), non-formal education aims at learning through new methodological possibilities, resulting from creativity and imagination, and also as collective representations, which lead the subject to understand his sociopolitical and cultural role. It is pertinent to conceive the space of the movie club "Mate com Angu" as a place that provides cultural activities to its visitors and an educational and non-formal environment that favors social, political, and cultural learning.

The short film entitled " $\mathrm{N}$ is my home" made by Lu Brasil received the 2 nd place award at the Popular Film Festival run by the movie club "Mate com Angu" in 2017. Using a smartphone, LB portrayed the struggle in favor of the public school Doutor Álvaro Alberto, also called by the nickname Mate com Angu, which runs the risk of being demolished, despite its historical importance, for the construction of a shopping mall.

Questioned about the awarded film, LB said:

Man! A company wants to destroy a school to build a mall, you know? I tried to do something too, because the mall doesn't satisfy me. The cultural circles of poetry and graffiti include me as a person. So I decided to make the film as a protest (Lu Brasil, 2018, interview). 
The meaning of film narratives is not exclusively individual but is constructed by the speeches of others who share their ideas, demands, questions, and opinions (Duarte, 2002). LB shared the personal protest but also heard the voices of several families, parents, and children from the local and school community as the agents of education, who are part of the struggle to maintain public education in the Duque de Caxias region. It is necessary for black women to construct their discourses to affirm that they are protagonists and knowledge-making subjects and not objects. Videomaker educator Lu Brasil reports this when she says:

"They say that we are the "Mimimi" [Victimisation] generation. But we really have to talk, we really have to complain, because otherwise, we will always stay in the slave quarters. When we graduate, when we achieve notoriety, visibility, the big house goes crazy... It goes crazy, understand? So if we don't do that, we never go ahead. [...] Brazil is still a very racist country" (Lu Brasil, 2018, interview).

\section{FINAL CONSIDERATIONS}

The absence of rights and services (access to jobs, health, schools, and recreation) is directed to the poor, mainly blacks and non-white people, who depend on social programs and have minimal income. The neoliberal policies, financial market, and local governments concentrate money and power among the hegemonic class, which, simultaneously, fears, excludes, imprisons, and kills the inhabitants of the periphery.

The representation of black women in Brazilian film narratives prioritizes stereotypes. They are marginalized, subordinated characters and are seen as sexual objects due to racial and gender prejudice. "Black women are excluded from directing and script activities and are the least represented group in the casts"; such productions are mostly made by white men, who hold the funding, expressing their narrative power in cinema (Candido and Feres Júnior, 2019, p. 10).

For all these reasons, art, music, and dance recreated by young, peripheral people are components of the Pedagogy of Survival (Oliveira, 2018).

Ferreira and LB have master's degrees in schooling. Both are social activists because they act for change. LB refutes the stereotypes against the Baixada Fluminense region by producing graffiti and films. Ferreira simultaneously teaches LIBRAS and the history and culture of deaf black people as responses to a kind of hypocrisy that shows that deafness can be accepted and blackness not. Her teaching as in advocacy praxis follows National Guidelines for LIBRAS Teaching (BRAZIL, 2002-2005) and Education of Racial and Ethnic Education (BRAZIL, 2004). These contents are included in formal education in the university

\section{REFERENCES}

Calixto, H. R. S. (2018). O Ensino de LIBRAS na Formação de Professores: Formas de Perceber o Surdo e a Língua de Sinais. Rio de Janeiro: Revista Interinstitucional Artes de Educar. doi: 10.12957/riae.2018.30063

Candido, M. R., and Feres Júnior, J. (2019). "Representação e estereótipos de mulheres negras no cinema brasileiro," in Revista Estudos Feministas, Vol. where she works, but Ferreira is also a member of a grassroots national movement-a non-formal education project-for the rights of deaf people. LB promotes workshops for children, teaching them her art and exercising new points of view about "their place," where they live, study, and play. This praxis of non-formal education aims to reduce violence. Both are black women who are aware of their condition as educators who act as educommunicators, creating visual and teaching materials, and this authorship can strengthen the identities of young women and children. Their lives are crossed by intersectionality.

The recognition of transformative potency inherent to subordinate classes has been one step to a decolonized education. It is not a mere exchange of words minimizing the realities such as femicide, drug traffic, and other crimes that happen in the BF region and other world cities. It is a creative way to learn about and how to access human rights and social justice.

Other black women are also being heard as African Brazilian religious leaders by students under an umbrella project called "Women Leading Education From Baixada Fluminense to the World." This work includes white women, indigenous women, and refugees... We are learning to learn (Delors, 2000) with them in order to include their experiences of life as cultural, political, and decolonized knowledge from BF. Each one has the potential for leadership and could expand their educational role to other people and places.

The standpoints of researchers and interviewees outlined "the questions we asked and the methods we used" (Shakeshaft, 2015 , p. 18) respecting both sides without hierarchy. Happily, we observed the understanding of both interviewees of our limitation as learners. Ironically, this article maintains the limitation resulting from the double translation of the thoughts expressed in LIBRAS into Portuguese and from Portuguese into English. This exercise can be considered a challenge, but without our participation in the WLE Conferences, maybe this effort would not have occurred because, in Brazil, the concept of leadership is not regularly employed in Education courses, as already mentioned above. These two young black women are protagonists, educommunicators, and social activists who defend education and black consciousness. Undeniably, both can and deserve to be classified as Women Leading in Education.

\section{AUTHOR CONTRIBUTIONS}

RM: coordinator of Afrodiásporas Research Center advising. LL: research about Black Deaf Women. TB: research about Lu Brasil a young black filmmaker. All authors contributed to the article and approved the submitted version. doi: 10.1590/S0102-69922016000100006

Coombs, P. H., and Ahmed, M. (1974). Attacking Rural Porverty: How Non-Formal Education Can Help. Baltimore, MD: John Hopkins University Press. 
Costa, A. R. C., and Bento, A. V. (2015). Práticas e comportamentos de liderança na gestão dos recursos humanos escolares. Ensaio: aval. pol. públ. Educ. 23, 663-680. doi: 10.1590/S0104-40362015000300006

Crenshaw, K. (2002). "A Intersecionalidade na Discriminação de Raça e Gênero," in Cruzamento: Raça e Gênero. Available online at: www.unifem.org.br/ sites/1000/1070/00000011.pdf

Delors, J. (2000). Educação: Um Tesouro a Descobrir - Relatório para a UNESCO da Comissão Internacional Sobre Educação Para o Século XXI. Brasília; São Paulo: MEC; UNESCO; Cortez.

Duarte, R. (2002). Cinema and Educação, 2nd Edn. Belo Horizonte: Autêntica Editora.

Ferreira, P. L. A. (2018). O ensino de relações étnico-raciais nos percursos de escolarização de negros surdos na educação básica.121f [Dissertação (mestrado)]. Universidade Estadual do Sudoeste da Bahia, Programa de Pós Graduação em Ensino - PPGEn, Vitória da Conquista, Brazil.

Freire, P. (1987). Pedagogia do Oprimido, 17a Edn. Rio de Janeiro: Paz e Terra.

Furtado, R. S. S. (2012). Narrativas Identitárias E Educação- Os Surdos Negros $\mathrm{Na}$ Contemporaneidade. Available online at: www.lume.ufrgs.br/ handle/10183/49810

Gewirtz, S., and Cribb, A. (2011). “Concepções plurais de Justiça Social: implicações para a sociologia das políticas,” in Políticas Educacionais: Questões e Dilemas, eds S. J. Ball and J. Mainardes (São Paulo: Revisão técnica de Márcia dos Santos Ferreira e Jefferson Mainardes), 499-509.

Gohn, M. G. (2014). Educação Não Formal, Aprendizagens e Saberes em Processos Participativos. Porto: Revista da Sociedade Portuguesa de Ciências da Educação: Investigar em Educação.

Gonzalez, L. (1988). A Importância da Organização da Mulher Negra no Processo de Transformação Social. Brasília: Raça e Classe.

Gonzalez, L. (2008). "Mulher negra," in Guerreiras de Natureza: Mulher Negra, Religiosidade e Ambiente, ed E. L. Nascimento (São Paulo: Selo Negro), 29-47.

Gonzalez, L., and Hasenbalg, C. (1982). Lugar de Negro. Rio de Janeiro: Raça, Classe e Mobilidade.

Guilherme, A., and Morgan, W. J. (2018). "Considering the role of the teacher: Buber, Freire and Gur-ZeÊev," in Educação \& Realidade (Porto Alegre), 783-798.

Hairston, E., and Smith, L. (1983). Black and Deaf in America: Are That Different. TJ Publishers, Inc.

Hasenbalg, C. (1979). Discriminação e Desigualdades Raciais no Brasil. Rio de Janeiro: Graal.

Hryniewicz, L. G. C., and Vianna, M. A. (2018). Mulheres em Posição de Liderança: Obstáculos e Expectativas de Gênero em Cargos Gerenciais Lygia Gonçalves. Rio de Janeiro.

Kaplun, M. (1999). Processos Educativos e Canais de Comunicação. Sao Paulo: Comunicaçao \& Educação.

Laudino, L. A. L. (2019). "Negros surdos - aprendendo a conhecer a dupla diferença," in TCC - Trabalho de Conclusão do Curso de Pedagogia sob a orientação de Rosangela Malachias. Duque de Caxias: Universidade do Estado do Rio de Janeiro, Faculdade de Educação da Baixada Fluminense.

Lawrence-Lightfoot, S. (1997). The Art and Science of Portraiture. San Francisco, CA: Jossey-Bass.

Lorde, A. (1984). “The Master's Tools Will Never Dismantle the Master's House," in Sister Outsider: Essays and Speeches, ed A. Lorde (New York, NY: The Crossing Press Feminist Series), 110-113.

Lumby, J. (2015). “Theorizing women leaders' experience: caught in the web, in Women Leading Educationn Across the Continents Overcoming the Barriers, eds C. E. Reilly and Q. J. Bauer (Lanham, MD: Rowman \& Littlefield Education), $157-163$.

Malachias, R. (2017). Interface Comunicação, Educação e Advocacy nas Práticas dos Movimentos Negros no Brasil. Revista Acadêmica Magistro do Programa de Pós-Graduação em Humanidades, Culturas e Artes - UNIGRANRIO.
Malachias, R. (2018). Mulheres Líderes em Educação. Da Baixada Fluminense para o Mundo Revista Interfaces Brasil-Canadá.

Malachias, R. (2019). "Mimimi? Não. Desigualdades, vulnerabilidades, corpo e comunicação," in Desigualdades, Gêneros e Comunicação, eds N. Prata and S. C. Pessoa (São Paulo: Intercom), 147-159.

Malachias, R., Reilly, E. C., and Fuller, K. (2018). "Sharing the spirit, fanning the flames of social justice," in PERIFERIA, Vol. 10 (Duque de Caxias), 5-12. doi: 10.12957/periferia.2018.35860

Mendes, I. A. C., Ventura, C. A. A., Trevizan, M. A., Marchi-Alves, L. M., and Souza-Junior, V. D. (2016). Educação, liderança e parcerias: potencialidades da enfermagem para a cobertura universal de saúde. Rev. Latino Am. Enfermagem 24:e2673. doi: 10.1590/1518-8345.1092.2673

Neves, L. G., and Coimbra, J. L. (2019). Evidence of the validity of the internal structure of the ethical, transformational and moral leadership scale in an educational Portuguese context. Paidéia 29:e2904. doi: 10.1590/1982-4327e2904

Neves, V. R., and Sanna, M. C. (2016). Conceitos e Práticas de Ensino e Exercício da Liderança em Enfermagem, Vol. 69. Brasília: Revista Brasileira de Enfermagem.

Oliveira, A. S. O. (2018). "O evangelho marginal dos Racionais MC's," in Racionais MC's - Sobrevivendo no Inferno/Racionais MC's - São Paulo, Companhia das Letras, 19-42.

Pinto, R. P. (1993). Movimento Negro e Educação do Negro: A Ênfase na Identidade. Fundação Carlos Chagas - Cad.

Rawls, J. (2002). "Uma Teoria da Justiça”" in Trad. Almiro Piseta e Lenita Maria Rímoli Esteves. 2 Edn (São Paulo: Martins Fontes), 201.

Santamaría, L. J., and Jaramillo, N. E. (2014). Comadres among us: the power of artists as informal mentors for women of color in academe. Mentor. Tutor. 22, 316-337. doi: 10.1080/13611267.2014.946281

Shakeshaft, C. (2015). "I'm not going to take this sitting down: the use and misuse of feminist standpoint theory in womens educational leadership," in Women Leading Education Across the Continents Overcoming the Barriers, eds E. C. Reilly and Q. Bauer (Lanham, MD: Rowman \& Littlefield Education), p. 15-18.

Silva, M. A. D. (2009). Religião, sexualidade e poder: a liderança religiosa e política dos evangélicos pentencostais $300 f$ Tese (Doutorado em Psicologia). Pontifícia Universidade Católica de São Paulo, São Paulo, Brazil.

Silva, M. V., and Viana, C. E. (2019). Communicative expression by means of Art: creating and reflecting on an intervention area of Educommunication. comunicação \& educação • Year XXIV • issue 1 • Jan/June.

Silva, R. R. D., and Holanda, A. F. A. (2008). Vivência de prazer e sofrimento no trabalho de líderes protestantes. Estud. Psicol. 25, 375-383. doi: 10.1590/S0103-166X2008000300006

Skliar, C., and Quadros, R. (2000). “- Dossiê - Invertendo Epistemologicamente o Problema da Inclusão. Os Ouvintes no Mundo dos Surdos," in Estilos da Clínica (São Paulo: Outubro), 32-51.

Soares, I. O. (2000). Educomunicação: um campo de mediaçães. Comun. Educ. 12-24. doi: 10.11606/issn.2316-9125.v0i19p12-24

Werneck, J. (2016). Racismo institucional e saúde da população negra. Saúde Soc. 25, 535-549. doi 10.1590/S0104-129020162610

Conflict of Interest: The authors declare that the research was conducted in the absence of any commercial or financial relationships that could be construed as a potential conflict of interest.

Copyright (c) 2020 Malachias, Laudino and Balbino. This is an open-access article distributed under the terms of the Creative Commons Attribution License (CC BY). The use, distribution or reproduction in other forums is permitted, provided the original author(s) and the copyright owner(s) are credited and that the original publication in this journal is cited, in accordance with accepted academic practice. No use, distribution or reproduction is permitted which does not comply with these terms. 